\title{
Perceived parenting and social support: can they predict academic achievement in Argentinean college students?
}

This article was published in the following Dove Press journal:

Psychology Research and Behavior Management

18 September 2014

Number of times this article has been viewed

\section{Guadalupe de la Iglesia ${ }^{1,2}$ Agustin Freiberg Hoffmann ${ }^{2}$ Mercedes Fernández Liporace $^{1,2}$}

'National Council of Scientific and Technical Research (CONICET), ${ }^{2}$ University of Buenos Aires, Buenos Aires, Argentina
Correspondence: Guadalupe de la Iglesia University of Buenos Aires, Gral Juan Lavalle 2353 (CI052AAA), Buenos Aires, Argentina

Tel +54 || 4952548 ।

Email gdelaiglesia@psi.uba.ar

\begin{abstract}
The aim of this study was to test the ability to predict academic achievement through the perception of parenting and social support in a sample of 354 Argentinean college students. Their mean age was 23.50 years (standard deviation $=2.62$ years) and most of them $(83.3 \%)$ were females. As a prerequisite for admission to college, students are required to pass a series of mandatory core classes and are expected to complete them in two semesters. Delay in completing the curriculum is considered low academic achievement. Parenting was assessed taking into account the mother and the father and considering two dimensions: responsiveness and demandingness. Perceived social support was analyzed considering four sources: parents, teachers, classmates, and best friend or boyfriend/girlfriend. Path analysis showed that, as hypothesized, responsiveness had a positive indirect effect on the perception of social support and enhanced achievement. Demandingness had a different effect in the case of the mother as compared to the father. In the mother model, demandingness had a positive direct effect on achievement. In the case of the father, however, the effect of demandingness had a negative and indirect impact on the perception of social support. Teachers were the only source of perceived social support that significantly predicted achievement. The pathway that belongs to teachers as a source of support was positive and direct. Implications for possible interventions are discussed.
\end{abstract}

Keywords: academic achievement, parenting, social support, college

\section{Introduction}

Academic achievement in Argentinean colleges is currently characterized by low performance. ${ }^{1-4}$ Passing classes and getting a degree are challenging for many students. Local researchers have started to analyze factors associated with academic achievement in order to provide an answer to this complex issue. The ultimate goal is designing and implementing tailored interventions to improve students' performance.

Traditionally, the study of factors related to academic achievement was mainly focused on the analysis of cognitive variables. Currently, the consideration of nonintellectual factors has taken the lead. ${ }^{5,6}$ Variables related to the students' environment, such as the role played by their parents and the students' perception of social support, have been linked to achievement. Notwithstanding, they are not usually analyzed on the whole, but using univariate statistics. ${ }^{7}$ This approach, despite its interest, is partial when considering that those variables occur simultaneously. Therefore, identifying and describing a feasible model to predict academic achievement, including factors such as perceived parenting and social support, may improve our understanding about the low performance of Argentinean college students. 


\section{Factors related to academic achievement}

Although the influence of intellectual variables on students' achievement has been acknowledged, ${ }^{8}$ their ability as predictors in real-world performance seems weak. ${ }^{9}$ In light of this, the focus on the analysis of non-intellectual aspects appears as an interesting proposal., 5

Most authors highlight the multicausality of academic achievement. Garbanzo Vargas ${ }^{10}$ classified them in three groups: personal, social, and institutional. The personal ones include intellectual abilities, personality traits, and psychological symptoms. Social factors encompass the assessment of those settings where students interact: family, peer groups, and residency. The institutional factors refer to the particular features of the organization where studies take place, including whether it is public or private, if classes are taken in the morning, afternoon, or evening, and evaluation methods.

Parents and the students' social support network are considered social factors. However, following cognitive perspectives, if they are defined as the students' perception of the socialization practices they get ${ }^{11}$ as well as the support they perceive, they should be classified as personal factors. As will be explained in the two following sections, perceived parenting and perceived social support were deemed able in partially explaining academic achievement.

\section{Academic achievement and perceived parenting}

Two main dimensions are usually considered when assessing perceived parenting: responsiveness and demandingness. Responsiveness refers to the amount of expressed warmth, affection, and time dedicated to dialogue. ${ }^{12}$ Demandingness includes parental strategies to regulate the offspring's behavior by setting limits, prohibitions, verbal and physical coercion, and other expressions of discipline. ${ }^{12}$

When trying to explain how parenting is related to students' performance, two main approaches come out. ${ }^{13-15}$ The first one states that responsive parenting practices contribute to creating a stimulating, supportive, and healthy environment that enhances achievement in their children. The second one understands responsiveness as a protective factor: students that perceive a high parental response will make use of more adaptive ways to cope with stressful situations, thus developing less psychopathological symptomatology. ${ }^{16-18}$ It has been stated that students who perceive their parents as responsive show better achievement. ${ }^{13-15,19-31}$

Conversely, the demandingness dimension has usually been related to worse academic performance. When parents were controlling, demanding, or aggressive, students did not perform well in school. ${ }^{14,16,25,26,32-34}$ These kinds of parenting practices are thought to inhibit development. ${ }^{13-15}$ Furthermore, highly demanding parents underestimate dialogue, block communication, and development of language skills. ${ }^{14}$

\section{Academic achievement and social support}

Social support has also been linked to academic achievement. Here, the assumption is that a higher perception of support functions as a buffer against stress. ${ }^{35}$ In this case the source of stress is the academic environment itself, which has often been considered stressful. ${ }^{36}$ Research has shown that social support seems to play this buffering role since it improves achievement at all educational levels. ${ }^{7,17,37-45}$

\section{Predicting academic achievement with applied purposes}

The University of Buenos Aires is a public university of Argentina and has the largest enrolment in the country. ${ }^{46}$ Students that want to start a college career are required to pass a two-semester mandatory entry class. Since admission requirements are minimal and tuition is free, classrooms are often overcrowded, even with hundreds of students. This is a major change for high school graduates who are used to more personalized teacher-student relationships. In addition, syllabus and exams are difficult, and most students take more time than expected to pass this entry class. Students' delays in completing this class not only indicate low achievement and a rough transition from high school to college, but also cause the public resources to be misused.

Tailored interventions on variables identified as predictors of academic achievement in this mandatory entry class could lead to the early detection of students at risk of academic failure, thus preventing such failure. ${ }^{47,48}$ The goals of this research consisted of: 1) testing the ability to predict academic achievement through the perception of parenting on the one hand, and social support on the other, in this mandatory entry class, and 2) outlining and testing the fit of a predictive model that included both factors simultaneously in a sample of local students who passed this entry class.

\section{Materials and methods Participants}

Participants were 354 Argentinean college students majoring in different degrees at the University of Buenos Aires (Psychology 59.4\%, Nutrition 25.9\%, Computer Engineering 6.2\%, Public Translator 5.6\%, and various $2.9 \%$ ). 
Ages varied from 19-35 years (mean 23.50 years, standard deviation 2.62 years). Most of them (83.3\%) were females. Also, the majority belonged to the medium socioeconomic level $(78.2 \%)$.

The sampling method was nonrandomized; participants were volunteers and were asked to sign an informed consent. Assessment took place in their classrooms. Since passing the two-semester mandatory class is a prerequisite to starting college and all of them were college students, all of the participants had already fulfilled this requirement. Therefore, students who did not pass the class (and consequently did not start their college courses) were excluded.

\section{Perceived Parenting Styles and Parental Inconsistency Scale (EPIPP)}

This 24-item scale assesses perceived parenting from the child's perspective, asking how they perceive their parents had raised them. This version was designed to be used in young adults and its psychometric properties have been analyzed by means of a pilot study, expert judgment, exploratory and confirmatory factor analyses, including factorial invariance and cross-validation studies, a test-retest procedure, and Cronbach's $\alpha$ as well as ordinals $\alpha{ }^{49,50}$ Although this scale allows the calculation of different scores such as parenting styles and parental inconsistency, only the responsiveness and demandingness scores were considered. The responsiveness dimension is composed of 13 items (eg, "My mother/father would have congratulated me if I had obtained a good grade at school"). The demanding dimension is composed of eleven items (eg, "My mother/father would have scolded me if I had left my stuff lying around the house"). All of them are answered using a four-point Likert scale that ranges from one (never) to four (always). Both dimensions were analyzed for both the mother and the father.

\section{Student social support scale}

The 15-item version, adapted to the local population, assesses perceived social support taking into account the academic environment. It examines four possible sources of support: parents (eg, "Give me advice"), teachers (eg, "Allow me to ask all the questions I need to"), classmates (eg, "Invite me to join them in their activities"), and best friend or girlfriend/ boyfriend (eg, "Helps me solve my problems"). The teacher scale has three items, the rest are composed of four items each. All of them are answered using a four-point Likert scale that ranges from one (never or almost never) to four (always or almost always). Its psychometric quality was studied in a pilot study, expert judgment, exploratory and confirmatory factor analyses, corrected homogeneity indexes, and Cronbach's $\alpha .{ }^{51-53}$

\section{Academic achievement in the mandatory entry class}

Students were asked about the amount of semesters they needed to pass the mandatory entry class. This mandatory class usually includes six subjects. All students must take Scientific Thinking and State and Society courses. The contents of the other four courses vary according to the degree the student wants to major in. A psychology student for example must take: Psychology, Biology, Math, and Semiotics. Other subjects for students who want to major in other degrees include Physics, Chemistry, Anthropology, Sociology, and Economics. Teachers and classmates are not constant throughout the different classes.

The University of Buenos Aires deems two semesters as the expected time to complete the six subjects included in the mandatory entry class. Considering this, two different categories were found: 1) high academic achievement: students who passed the class in the expected time (two semesters or less), and 2) low academic achievement: students who passed the class exceeding the expected time (three semesters or more).

\section{Results}

In order to analyze which variables should be included in the model to predict academic achievement, univariate logistic regressions were calculated. Results showed that only perceived support from teachers was a statistically significant predictor (Table 1). Mother demandingness was just over the bounds of significance $(P=0.051)$.

A prediction model for academic achievement was specified taking into account these results and the theoretical background. The pathway started with the perception of parenting (represented by the two dimensions: demandingness and responsiveness), going on to perceived social support (measured in terms of each source of support), and finally on to academic achievement (Figure 1). This was tested separately for the father and for the mother.

The estimation method used was maximum likelihood. A bootstrap procedure that generated 500 random samples was used to examine the stability of the results. Additionally, a Bayesian estimation was calculated because the final variable was dichotomous (high versus low academic achievement). ${ }^{54}$

The model for perceived parenting from the father showed a good fit (goodness of fit index $=0.998$; adjusted goodness of fit 


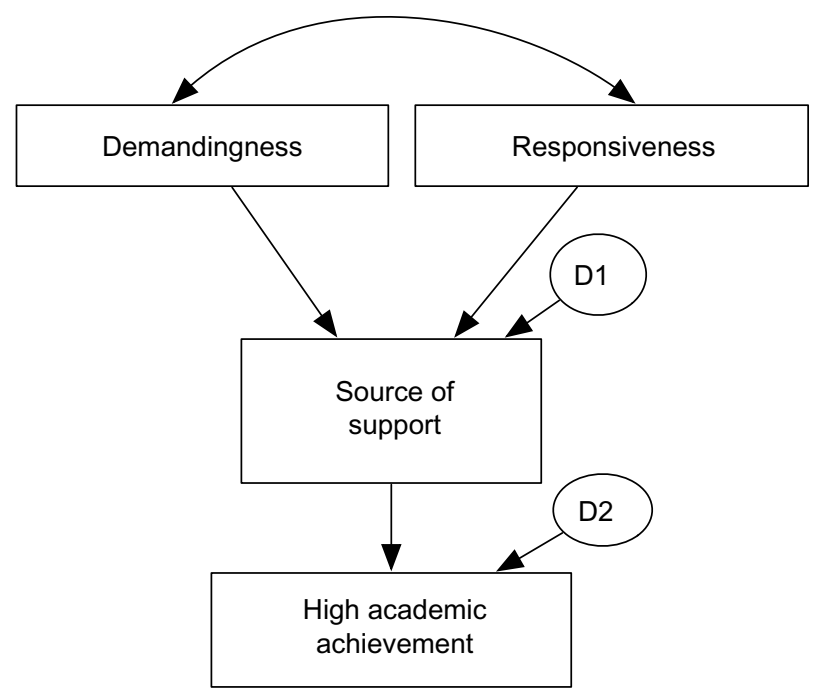

Figure I Hypothesized model to predict academic achievement. Abbreviation: $\mathrm{D}$, disturbance.

index $=0.988$; standardized root mean square residual $=0.021$; comparative fit index $=1$; normed fit index $=0.949$; root mean square error of approximation $=0[90 \%$ confidence interval $0.000-0.101])$. All paths were statistically significant, and parameters by maximum likelihood and Bayesian estimations were similar (Table 2).

All paths had the expected results (Figure 2). Responsiveness had a positive effect on social support, and demandingness had a negative one. Teacher support had a positive effect on academic achievement. The explained variance for academic achievement was $1.8 \%$.

When testing the same model but in the case of the mother, the path from demandingness to teacher support was nonsignificant. In view of this and considering the results of the logistic regressions, where mother demandingness approached the level of significance $(P=0.051)$, the model was respecified to measure the direct effect of demandingness on academic achievement. The respecified model showed a good fit (goodness of fit index $=0.999$; adjusted goodness of fit index $=0.996$; standardized root mean square residual $=0.012$; comparative fit index $=1$; normed fit index $=0.983$; root mean square error of approximation $=0$ [ $90 \%$ confidence interval $0.000-0.071]$ ), with all parameters showing statistical significance for maximum likelihood as well as for the Bayesian estimation (Table 3).

Figure 3 exhibits a direct positive effect of demandingness on academic achievement, and an indirect positive effect of mother responsiveness through the perception of social support from teachers. The explained variance for academic achievement was $3 \%$. 
Table 2 Predictive model for high academic achievement: the father case

\begin{tabular}{|c|c|c|c|c|c|c|c|c|}
\hline \multirow[t]{3}{*}{ Exogenous } & & \multirow[t]{3}{*}{ Endogenous } & \multicolumn{3}{|c|}{ Standardized parameters } & \multirow[t]{3}{*}{$P$-value } & \multirow{2}{*}{\multicolumn{2}{|c|}{$\begin{array}{l}\text { Non-standardized } \\
\text { parameters }\end{array}$}} \\
\hline & & & \multirow[t]{2}{*}{ Mean } & \multirow[t]{2}{*}{ Inferior } & \multirow[t]{2}{*}{ Superior } & & & \\
\hline & & & & & & & ML & Bayes \\
\hline Father responsiveness & $\rightarrow$ & Teachers' social support & 0.190 & 0.081 & 0.284 & 0.004 & 0.020 & 0.020 \\
\hline Father demandingness & $\rightarrow$ & Teachers' social support & -0.115 & -0.216 & 0.001 & 0.052 & -0.016 & -0.016 \\
\hline Teachers' social support & $\rightarrow$ & High academic achievement & 0.134 & 0.031 & 0.243 & 0.018 & 0.095 & 0.093 \\
\hline
\end{tabular}

Abbreviation: ML, maximum likelihood.

\section{Discussion}

The main goal of this research was to test the ability to predict academic achievement in a mandatory entry class required at the start of college with a model that included perceived parenting and social support simultaneously. Initially, univariate logistic regressions were carried out to outline the model. Despite the fact that perceived parenting was supposed to be directly associated to academic achievement, ${ }^{13-15,19-29}$ only mother demandingness was shown to be almost significantly related. This lack of statistical significance may be due to two main elements.

Firstly, participants were college students and not elementary or high school students, as in most studies previously referred to. ${ }^{13-29,32-34}$ Differences in the age group studied seem to be one of the causes. Developmental issues may play a major role in these results. It seems logical that the statement about the direct influence of parenting in children and adolescents' achievement might not be extended to young adulthood. The influence of

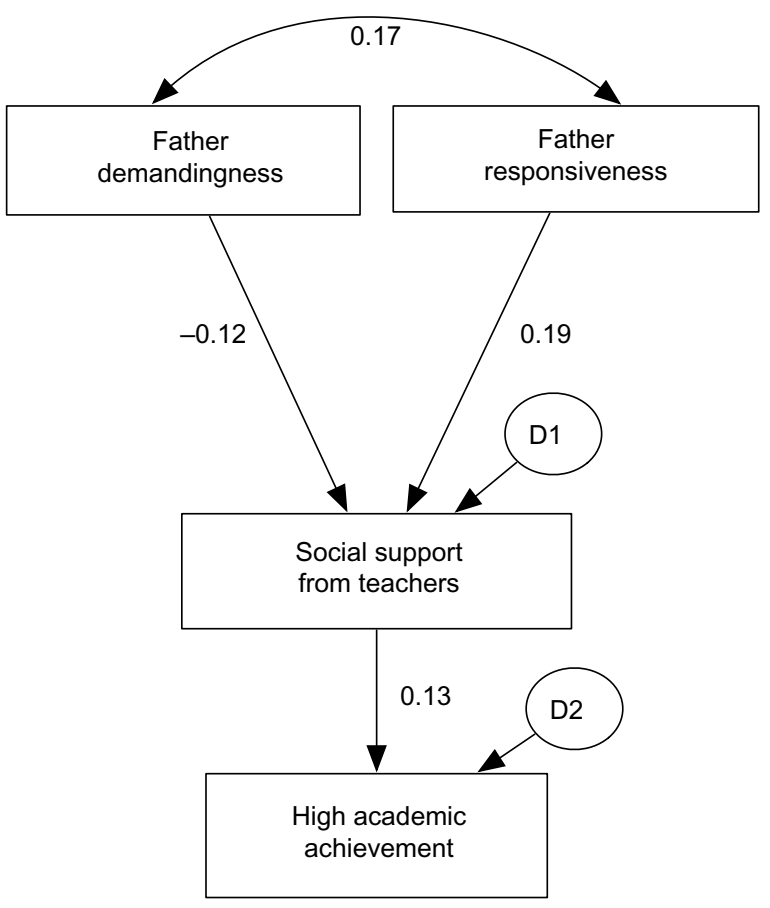

Figure 2 Predictive model for high academic achievement: the father case. Abbreviation: D, disturbance. perceived parenting may decline as students grow up and its effects remain only through secondary variables.

Secondly, measures of academic achievement could also have introduced dissimilarities. The indicator employed here was passing a mandatory entry class as a prerequisite for admission to college within the stipulated time (two semesters). Former studies, on the other hand, measured performance through school tests or grade point average. ${ }^{13-29,32,34}$ The use of grade point average was not possible in this research since access to the university records is extremely difficult due to confidentiality restrictions set forth by the institution. In this matter, it must also be remarked that reliability of the self-report measure is a limitation that could influence the results as well.

As for perceived social support, teachers were the only source related to academic achievement. This arises as a finding of interest for Argentinean educators if you consider the characteristics of local public education. Since admission to this mandatory entry class is not selective and almost any resident with a high school diploma can take it, classes are crowded often with hundreds of students. This has a high impact on the student-teacher relationship, since the teachers are hardly available to students. However, these results show that teachers do play an important role in students' performance in this entry class. As evidenced by previous research, social support enhanced academic achievement, probably by buffering the stressful conditions of academic life. . $17,35-45^{-1}$

Proceeding now to the interpretation of the prediction models tested by path analyses, where the variables were studied jointly, it must be noted that fit indexes were adequate. The root mean square error of approximation index was zero because $\chi^{2}$ was less than the degrees of freedom in both models. This means that the models were perfectly specified reflecting exact model fit. ${ }^{55}$

When observing path analyses, relationships within variables became clearer. In both models, responsiveness favored the perception of support from the teachers who, additionally, had a positive impact on academic achievement. It seems reasonable that students with parents that provided loving and supportive environments, where dialogue was valued, seek or perceive similar bonds with other important 
Table 3 Predictive model for high academic achievement: the mother case

\begin{tabular}{|c|c|c|c|c|c|c|c|c|}
\hline \multirow[t]{3}{*}{ Exogenous } & & \multirow[t]{3}{*}{ Endogenous } & \multicolumn{3}{|c|}{ Standardized parameters } & \multirow[t]{3}{*}{$P$-value } & \multirow{2}{*}{\multicolumn{2}{|c|}{$\begin{array}{l}\text { Non-standardized } \\
\text { parameters }\end{array}$}} \\
\hline & & & \multirow[t]{2}{*}{ Mean } & \multirow[t]{2}{*}{ Inferior } & \multirow[t]{2}{*}{ Superior } & & & \\
\hline & & & & & & & ML & Bayes \\
\hline Mother responsiveness & $\rightarrow$ & Teachers' social support & 0.199 & 0.085 & 0.306 & 0.004 & 0.023 & 0.023 \\
\hline Teachers' social support & $\rightarrow$ & High academic achievement & 0.134 & 0.035 & 0.242 & 0.013 & 0.095 & 0.095 \\
\hline Mother demandingness & $\rightarrow$ & High academic achievement & 0.105 & 0.016 & 0.199 & 0.028 & 0.009 & 0.009 \\
\hline
\end{tabular}

Abbreviation: ML, maximum likelihood.

socialization agents - the teachers. This leads to an enabling college performance.

Demandingness played a different role in each model. In the case of the father, the negative indirect path from demandingness to academic achievement ran in the same direction as previous studies, , 14,16,25,26,32-34 ie, a high perception of demandingness was related to low achievement through the perception of social support. Surprisingly, in the mother model, demandingness had a direct positive effect on academic achievement. Suggesting any conclusions from these analyses is daring, for they would be inconsistent with previous research as well as theoretical hypotheses which state that a higher perception of demandingness should be linked to a lower achievement. Again, this inconsistency may relate to the two points mentioned above: the age group and the measuring method employed for academic achievement.

When considering the limitations of the study, one rests on the female prevalence in the sample. However, this disproportion represents pretty accurately the picture in an

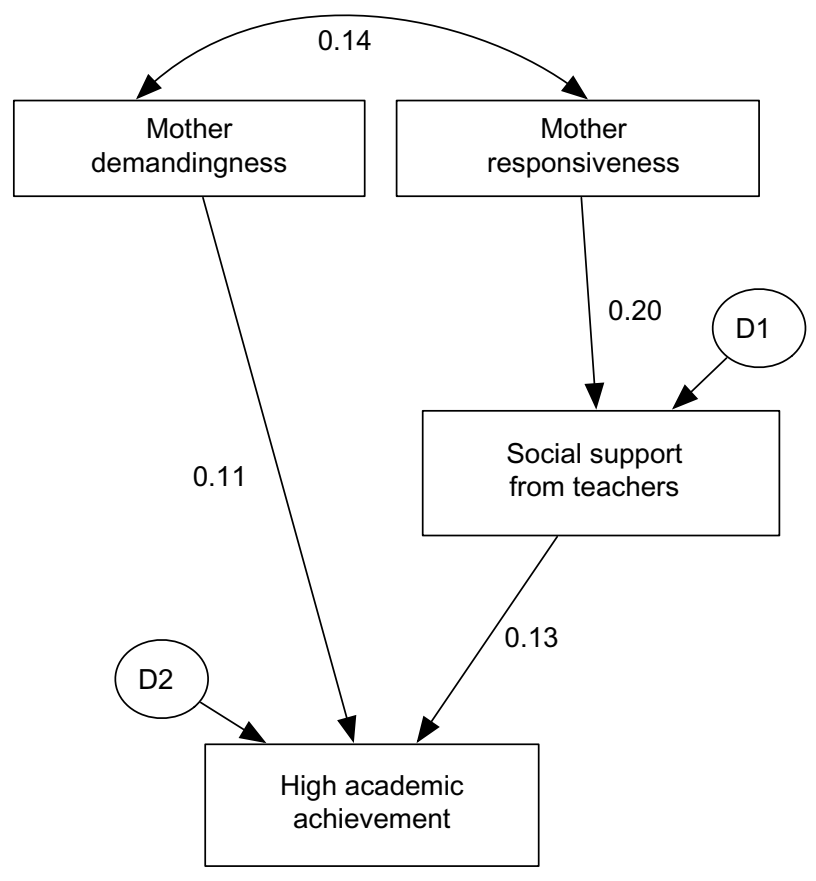

Figure 3 Predictive model for high academic achievement: the mother case. Abbreviation: D, disturbance.
Argentinean college population. ${ }^{56}$ Also, students who did not pass the entry class were left out and no information was retrieved regarding the delay in completing the class due to medical or other reasons. This could bias the results obtained. Plus, although the University of Buenos Aires expects that all students complete this class in two semesters, only two of the six courses are the same for all of them. The remaining four differ according to the degree they want to major in. Dissimilarities in the difficulty of the content could play a role in the delay in completing the mandatory entry class.

Moreover, the low explained variance in the predictive model must be remarked upon. This was not surprising since predictors included here were supposed to be significant but stated to estimate academic achievement only partially. The study never intended to explain the achievement completely. Actually, $\mathrm{Cobb}^{57}$ stated, for instance, that although social support functions as a protective factor, it is not an absolute solution against personal discomfort and large main effects should not be expected. Notwithstanding the low variance, it must be pointed out that all paths were statistically significant and went in the expected direction according to the theoretical and empirical background.

When thinking about the implications of these findings, the suggestion of interventions on parenting may seem controversial. Nonetheless, there is an increasing interest in parenting training programs aimed at promoting healthy socialization practices. ${ }^{58,59}$ Although discussing these programs is beyond the aims of this paper, it seems interesting to point out that it is possible to teach people how to raise their children in ways that will probably impact on their general adaptation and particularly on their performance in college.

Regarding the idea of empowering teacher support, the space for tutoring hours comes up. Providing a space that promotes student-teacher interactions could benefit academic achievement since students' perception of feeling supported may increase. Indeed, tutoring has been found to constitute a factor linked to a better academic performance. ${ }^{44,60,61}$ Additionally, tutoring does not necessarily entail a big money expense since brief training has shown to have a later positive impact in students' autonomy in the school. ${ }^{62}$ 
In this matter, Argentinean public colleges provide more ideas than concrete facts. ${ }^{63}$ Although tutoring should be regular practice and college authorities acknowledge this need, currently there are no tutoring spaces available for students. Implementing this type of support would allow high school graduates to experience a more mellow and guided transition to college, generating more independent students. Tutoring could function as a buffer to the stress implicit in a demanding syllabus and difficulties in seeking teachers' advice due to overcrowded classes.

Since teachers appear to play a more important role in students' success in this mandatory entry class than formerly thought, the teachers ought to be the focus of any intervention. Incorporating more teachers so that the responsibility of instruction does not lie just with one person could be another feasible strategy to enhance the perception of teacher support. This does not necessarily imply a big expense since many recently graduated professionals are willing to collaborate as teachers in the public university they graduated from. Assisting the teacher in charge of the course is important for their own learning since it involves the opportunity to interact and learn from someone with more experience in the field and consolidate theoretical concepts, ie, it provides a role in which recent graduates can continue their professional training.

Future research may test the effectiveness of the implementation of tutoring hours or the inclusion of assistants to the teachers in the classroom. Also, since variance was low, new studies should examine the role of other non-intellectual variables in order to increase knowledge on the multicausality of academic achievement.

\section{Disclosure}

The authors report no conflicts of interest in this work.

\section{References}

1. [Deans and rectors acknowledge that high desertion is a weak point] [webpage on the Internet]. Buenos Aires: Clarin; 2011 [cited August 26, 2011]. Available from: http://www.clarin.com/educacion/Decanosrectores-reconocen-desercion-punto_0_542945805.html. Accessed December 10, 2012. Spanish.

2. Guadagni AA. [We need more college graduates] [webpage on the Internet]. Buenos Aires: Clarin; 2012 [cited November 22, 2012]. Available from: http://www.clarin.com/opinion/Necesitamos-graduadosuniversitarios_0_815318529.html. Accessed August 6, 2014. Spanish.

3. Premat S. [Few finish college] [webpage on the Internet]. Buenos Aires: Clarin; 2011 [cited February 24, 2011]. Available from: http://www. lanacion.com.ar/1352491-pocos-terminan-la-universidad. Accessed August 6, 2014. Spanish.

4. Sigal P. [Controversy over the amount of college graduates] [webpage on the Internet]. Buenos Aires: Clarin; 2011 [cited August 26, 2011]. Available from: http://www.clarin.com/educacion/Polemica-cantidadgraduados-universidades_0_542945804.html. Accessed August 6, 2014. Spanish.
5. Grimm KJ, Steele JS, Mashburn AJ, Burchinal M, Pianta RC. Early behavioral associations of achievement trajectories. Dev Psychol. 2010;46(5):976-983.

6. Tripicchio P. [It is not a synonymous of academic success] [webpage on the Internet]. Buenos Aires: Clarin; 2011 [cited April 12, 2011] Available from: http://www.clarin.com/sociedad/sinonimo-exitoacademico_0_461354029.html. Accessed August 6, 2014. Spanish.

7. Rosenfeld LB, Richman JM, Bowen GL. Social support networks and school outcomes: the centrality of the teacher. Child Adolesc Social Work J. 2000;17(3):205-226.

8. Duncan GJ, Dowsett CJ, Claessens A, et al. School readiness and later achievement. Dev Psychol. 2007;43(6):1428-1446.

9. Sternberg RJ, Wagner RK, Williams WM, Horvath JA. Testing common sense. Am Psychol. 1995;50(11):912-927.

10. Garbanzo Vargas GM. [Factors associated with academic achievement in college students, a reflection from the public superior education quality]. Revista Educacion. 2007;31(1):43-63. Spanish.

11. Ausubel DP, Balthazar EE, Rosenthal I, Blackman LS, Schpoont SH, Welkowitz J. Perceived parent attitudes as determinants of children's ego structure. Child Dev. 1954;25(3):173-183.

12. Baumrind D. The discipline controversy revisited. Family Relations: Interdisciplinary Journal of Applied Family Studies. 1996;45(4):405-414.

13. Bean RA, Bush KR, McKenry PC, Wilson SM. The impact of parental support, behavioral control, and psychological control on the academic achievement and self-esteem of African American and European American adolescents. J Adolesc Res. 2003;18(5):523-541.

14. Coley RL, Lewin-Bizan S, Carrano J. Does early paternal parenting promote low-income children's long-term cognitive skills? J Fam Issues. 2011;32(11):1522-1542.

15. De Von Figueroa-Moseley C, Ramey CT, Keltner B, Lanzi RG. Variations in Latino parenting practices and their effects on child cognitive developmental outcomes. Hisp J Behav Sci. 2006;28(1):102-114.

16. Swanson J, Valiente C, Lemery-Chalfant C, O'Brien TC. Predicting early adolescents' academic achievement, social competence, and physical health from parenting, ego resilience, and engagement coping. J Early Adolesc. 2011;31(4):548-576.

17. Crean HF. Social support, conflict, major life stressors, and adaptive coping strategies in Latino middle school students: an integrative model. J Adolesc Res. 2004;19(6):657-676.

18. Rohner RP. Perceived teacher acceptance, parental acceptance, and the adjustment, achievement, and behavior of school-going youths internationally. Cross Cult Res. 2010;44(3):211-221.

19. Ellefsen G, Beran TN. Individuals, families, and achievement: a comprehensive model in a Canadian context. Canadian Journal of School Psychology. 2007;22(2):167-181.

20. Fletcher AC, Steinberg L, Sellers EB. Adolescents' well-being as a function of perceived interparental consistency. J Marriage Fam. 1999;61(3):599-610.

21. Gringlas M, Weinraub M. The more things change ... single parenting revisited. J Fam Issues. 1995;16(1):29-52.

22. IrukaIU, Burchinal M, Cai K. Long-term effect of early relationships for African American children's academic and social development: an examination from kindergarten to fifth grade. J Black Psychol. 2010;36(2):144-171.

23. Khan S, Haynes L, Armstrong A, Rohner RP. Perceived teacher acceptance, parental acceptance, academic achievement, and school conduct of middle school students in the Mississippi Delta region of the United States. CrossCult Res. 2010;44(3):283-294.

24. Kim K, Rohner RP. Parental warmth, control, and involvement in schooling: predicting academic achievement among Korean American adolescents. J CrossCult Psychol. 2002;33(2):127-140.

25. Lakshmi AR, Arora M. Perceived parental behaviour as related to student's academic school success and competence. Journal of the Indian Academy of Applied Psychology. 2006;32(1):47-52.

26. Leung CYW, McBride-Chang C, Lai BPY. Relations among maternal parenting style, academic competence, and life satisfaction in Chinese early adolescents. J Early Adolesc. 2004;24(2):113-143. 
27. Mattanah JF. Parental psychological autonomy and children's academic competence and behavioral adjustment in late childhood: more than just limit-setting and warmth. MerrillPalmer Q. 2001;47(3):355-376.

28. Sapienza G, Aznar-Farias M, Silvares EFM. [Social competence and parental educational practices in adolescents with high and low academic achievement]. Psicologia Reflexao e Critica. 2009;22(2): 208-213. Portuguese.

29. Saracho O. Hispanic families as facilitators of their children's literacy development. J Hispanic High Educ. 2007;6(2):103-117.

30. Silva M, Dorso E, Azhar A, Renk K. The relationship among parenting styles experienced during childhood, anxiety, motivation, and academic success in college students. J Coll StudRet. 2007;9(2):149-167.

31. Turner EA, Chandler M, Heffer RW. The influence of parenting styles, achievement motivation, and self-efficacy on academic performance in college students. J Coll Stud Dev. 2009;50(3):337-346.

32. Shumow L, Vandell DL, Posner JK. Harsh, firm, and permissive parenting in low-income families: relations to children's academic achievement and behavioral adjustment. J Fam Issues. 1998;19(5):483-507.

33. Veltman MW, Browne KD. Three decades of child maltreatment research: implications for the school years. Trauma Violence Abuse. 2001;2(3):215-239.

34. Wentzel KR, Feldman S, Weinberger DA. Parental child rearing and academic achievement in boys: the mediational role of social-emotional adjustment. J Early Adolesc. 1991;11(3):321-339.

35. Cohen S, Wills TA. Stress, social support, and the buffering hypothesis. Psychol Bull. 1985;98(2):310-357.

36. Shokri O, Farahani MN, Nouri RK, Moradi AR. Perceived social support and academic stress: the roles of gender and cultural differences. Developmental Psychology: Journal of Iranian Psychologists. 2013; 9(34):143-156.

37. Domagala-Zysk E. The significance of adolescents' relationships with significant others and school failure. Sch Psychol Int. 2006;27(2): 232-247.

38. Elias MJ, Haynes NM. Social competence, social support, and academic achievement in minority, low-income, urban elementary school children. Sch Psychol Q. 2008;23(4):474-495.

39. Garcia D’Avila-Bacarji KM, Marturano EM, dos Santos Elias LC. [Parental support: a study about children with school complaints]. Psicologia em Estudo. 2005;10(1):107-115. Portuguese.

40. Jun-Li Chen J. Perceived academic support from parents, teachers, and peers: relation to Hong Kong adolescents' academic behavior and achievement (family involvement research digest) [webpage on the Internet]. Cambridge, MA: Harvard Family Research Project; 2005. Available from: http://www.hfrp.org/family-involvement/ publications-resources/perceived-academic-support-from-parentsteachers-and-peers-relation-to-hong-kong-adolescents-academicbehavior-and-achievement. Accessed December 10, 2012.

41. Konishi C, Hymel S, Zumbo BD, Li Z. Do school bullying and studentteacher relationships matter for academic achievement? A multilevel analysis. Canadian Journal of School Psychology. 2010;25(1):19-39.

42. Malecki CK, Demaray MK. What type of support do they need? Investigating student adjustment as related to emotional, informational, appraisal, and instrumental support. Sch Psychol Q. 2003;17(3): 213-241.

43. Perry JC, Liu X, Pabian Y. School engagement as a mediator of academic performance among urban youth: the role of career preparation, parental career support, and teacher support. Couns Psychol. 2010;38(2): 269-295.

44. Bordes-Edgar V, Arredondo P, Robinson Kurpius S, Rund J. A longitudinal analysis of Latina/o students' academic persistence. J Hispanic High Educ. 2011;10(4):358-368.

45. Cutrona CE, Cole V, Colangelo N, Assouline SG, Russell DW. Perceived parental support and academic achievement: an attachment theory perspective. J Pers Soc Psychol. 1994;66(2):369-378.
46. Coordinacion General de Planificacion Estrategica e Institucional. [2011 Student Census]. Buenos Aires: Universidad de Buenos Aires; 2011. Available from: http:/www.uba.ar/institucional/censos/Estudiantes2011/ estudiantes\%202011.pdf. Accessed August 6, 2014. Spanish.

47. Operativo Nacional de Evaluacion. [Census on High School Graduation]. Buenos Aires: Operativo Nacional de Evaluacion; 2010. Available from: http://diniece.me.gov.ar/images/stories/diniece/evaluacion_educativa/ nacionales/re sultados/Resultados\%20Censo\%20ONE\%202010.pdf. Accessed December 10, 2012. Spanish.

48. Organizacion para la Cooperacion y Desarrollo Economico. [Program for International Student Assessment 2009]. Madrid: Ministerio de Educacion; 2010. Available from: http://iaqse.caib.es/documents/aval2009-10/ pisa2009-informe-espanol.pdf. Accessed August 6, 2014. Spanish.

49. de la Iglesia G, Ongarato P, Fernandez Liporace M. [Psychometric properties of a perceived parenting styles and inconsistency scale]. Evaluar. 2010;10:32-52. Spanish.

50. de la Iglesia G, Stover JB, Freiberg Hoffmann A, Fernandez Liporace M. Perceived Parenting Styles and Parental Inconsistency Scale: construct validity in young adults. Int J Humanit Soc Sci. 2014;4(7-1):61-69.

51. Nolten PW. Conceptualization and Measurement of Social Support: The Development of the Student Social Support Scale [unpublished doctoral thesis]. Madison, WI: University of Wisconsin; 1994.

52. Fernandez Liporace M, Ongarato P. [Adaptation of the Social Support Scale for Students in adolescents of Buenos Aires]. Perspectivas en Psicologia, Revista de Psicologia y Ciencias Afines. 2005;2(1):43-50. Spanish.

53. Fernandez Liporace M, Castro Solano A, Contini de Gonzalez N. [Social support in adolescent students: generalization of the factorial structure of a scale in different groups]. Revista de Psicologia General y Aplicada. 2006;59:131-148. Spanish.

54. Byrne BM. Structural Equation Modeling with AMOS. Basic Concepts, Applications, and Programming. New York, NY: Taylor and Francis: 2010.

55. Chen F, Curran PJ, Bollen KA, Kirby J, Paxton P. An empirical evaluation of the use of fixed cutoff points in RMSEA test statistic in structural equation models. Sociol Methods Res. 2008;36(4):462-494.

56. Lopez Cleip De Sosa AB, Amoroso De Maza MT. [Feminization of the college enrollment]. Poster presented at: V Encuentro Nacional y II Latinoamericano La Universidad Como Objeto de Investigacion; August 30-September 1, 2007; Buenos Aires, Argentina. Spanish.

57. Cobb S. Social support as a moderator of life stress. Psychosom Med. 1976;38(5):300-314.

58. Catalano RF, Kosterman R, Haggerty K, Hawkins JD, Spoth RL. A universal intervention for the prevention of substance abuse: preparing for the drug-free years. In: Ashery RS, Robertson EB, Kumpfer KL, editors. Drug Abuse Prevention Through Family Interventions. Rockville, MD: National Institute on Drug Abuse; 1998:130-159.

59. Kaminski JW, Valle LA, Filene JH, Boyle CL. A meta-analytic review of components associated with parent training program effectiveness. J Abnorm Child Psychol. 2008;36(4):567-589.

60. Gloria AM, Kurpius SE. Influences of self-beliefs, social support, and comfort in the university environment on the academic nonpersistence decisions of American Indian undergraduates. Cultur Divers Ethnic Minor Psychol. 2001;7(1):88-102.

61. Malik S. Students, tutors, and relationships: the ingredients of a successful student support scheme. Med Educ. 2000;34(8):635-641.

62. McLachlan S, Hagger MS. Effects of an autonomy-supportive intervention on tutor behaviors in a higher education context. Teaching and Teacher Education. 2010;26(5):1204-1210.

63. Geddes D. [We will implement tutoring hours in high school in order to improve achievement in the $\mathrm{CBC}$ ] [webpage on the Internet]. Buenos Aires: Clarin; 2013 [cited December 6, 2013]. Available from: http://www. clarin.com/edicion-impresa/Pondremos-tutorias-secundario-desempenoCBC_0_1042695752.html. Accessed August 6, 2014. Spanish. 
Psychology Research and Behavior Management

Dovepress

\section{Publish your work in this journal}

Psychology Research and Behavior Management is an international, peerreviewed, open access journal focusing on the science of psychology and its application in behavior management to develop improved outcomes in the clinical, educational, sports and business arenas. Specific topics covered include: Neuroscience, memory \& decision making; Behavior modification \& management; Clinical applications; Business \& sports performance management; Social and developmental studies; Animal studies. The manuscript management system is completely online and includes a quick and fair peer-review system. Visit http://www.dovepress. com/testimonials.php to read real quotes from published authors.

Submit your manuscript here: http://www.dovepress.com/psychology-research-and-behavior-management-journal 